\title{
Havacılık Yönetimi Lisans Öğrencilerinin Meslek Tercih Eğilimlerinin İncelenmesi
}

\begin{abstract}
Seyhun DURMUŞ ${ }^{1}$ iD
Emre Osman TOKYAY²

\begin{tabular}{|lll|}
\hline Araştırma Makalesi & DOI: $10.51785 /$ jar.945831 & \\
\hline Gönderi Tarihi: 31.05 .2021 & Kabul Tarihi: 26.07 .2020 & Online Yayın Tarihi: 29.08 .2021 \\
\hline
\end{tabular}

Mevcut çalışma, lisans düzeyinde örgün eğitim veren devlet üniversitelerindeki havacılık yönetimi bölümünü tercih eden öğrencilerin tercih eğilimlerinin ölçülmesi ve öğrencilerin bölüm dışındaki ilgi duydukları mesleklerin analiz edilmesini hedeflemektedir. Literatürde havacılık yönetimi bölümünü tercih eden öğrencilerin tercih eğilimlerine yönelik yeterli düzeyde çalışma olmaması mevcut çalışmanın motivasyonudur. Çalışmada veri kaynağı olarak Yükseköğretim Program Atlası kullanılmıştır. Çalışmada toplamda 18693 tercih verisi işlenmiştir. Tüm veriler bazında yapılan tercihlerin \%37,24 oranında havacılık yönetimine odaklandığ anlaşılmıştır. Tekil veriler bazında ise fakülte ve yüksekokullarda 2 ayrı bloğun oluştuğu gözlemlenmiştir. Yüksek YKS taban puanı olan 1. Blokta havacılık yönetiminin tercih oranları \%20 bandındayken; düşük YKS taban puanı olan 2. Blokta tercih oranları \%40 bandındadır. Yüksek taban puanlar ile tercih edilen bölümlerde öğrencilerin daha çok YKS puanını baz aldıkları öne sürülebilir; çünkü bu öğrenciler düşük puanlı havacılık yönetimi bölümünü tercih etmek yerine sınıf öğretmenliği ve rehberlik ve psikolojik danışmanlık gibi bölümleri tercih etmişlerdir. Analiz sonucunda öğrencilerin bölüm dışındaki ilgi duydukları bölümlerin başını, \%8,74'lük oranla sınıf öğretmenliği, \%5,13'lük oranla rehberlik ve psikolojik danışmanlık ve\%4,13'lük oranla yönetim ve yönetim bilişim sistemleri bölümleri olduğu sonucuna varılmıştır. Bu bölümleri; psikoloji $(\% 3,34)$, sağlık yönetimi $(\% 3,34)$ ve sosyal hizmet $(\% 2,44)$ gibi bölümler takip etmektedir. Çalışmada; havacılık yönetimi bölümünün güncel bir tahlili yapılmış, öğrencilerin tercihlerdeki tercih eğilim düzeyini fakülte ve yüksekokul bloklarında analiz edilerek öğrencilerin eğilimli oldukları meslekler ortaya çıkarılmıştır.
\end{abstract}

\section{$\ddot{O} z$}

Anahtar Kelimeler: Sivil Havacılık, Havacılık Yönetimi, Tercih Eğilimi, Meslek Seçimi

JEL Sinıflandirma: M10, M19.

\section{Examination of the Career Choice Trends of Aviation Management Undergraduate Students}

\begin{abstract}
The present study aims to measure the career choice trends of students who prefer the aviation management department in state universities that provide formal education at the undergraduate level and to analyze the professions that students are interested in out of aviation management program. The lack of sufficient studies on the student's career choice trends who prefer the aviation management department in the literature is the motivation of the current study. The Atlas of Higher Education Programs (YOK ATLAS) was used as a source of data. A total of 18693 preference data were processed in the study. As a result of the analysis, it can be assumed that $37.24 \%$ of choice on the basis of all data are focused on aviation management. On the basis of individual data, it was observed that 2 separate blocks were formed in faculties and colleges. While the preference rates of aviation management in the 1st Block, which has a high YKS base score, are in the $20 \%$ band; In the 2nd Block, which has a low YKS base score, preference rates are in the $40 \%$ band. It can be argued that students in departments preferred with high base scores mostly rely on their YKS score; because these students preferred departments such as classroom teaching and guidance and psychological counseling instead
\end{abstract}

\footnotetext{
${ }^{1}$ Dr. Öğr. Üyesi Balıkesir Üniversitesi, drmsyhn@gmail.com

${ }^{2}$ Lisans Öğrencisi, Samsun Üniversitesi, eotokyay@gmail.com
} 
of choosing the department of aviation management with a low score. As a result of the analysis, it was concluded that the main departments that students were interested in out of aviation management were classroom teaching with $8.74 \%$, guidance and psychological counseling with $5.13 \%$, and management and management information systems with $4.13 \%$. These programs are followed by programs such as psychology (3.34\%), health management (3.34\%) and social work (2.44\%). In the study; a current analysis of the aviation management department has been made, the students' carreer choice trends have been analyzed in the faculties and college blocks, and the professions that the students are inclined towards are revealed.

Key Words: Civil Aviation, Aviation Management, Trend of Preference, Career Choice

JEL Classification: M10, M19.

\section{GíRiş}

Ülkemizde sivil havacılık sektörünün ihtiyaç duyduğu nitelikli insan gücünü yetiştirmek amacıyla çoğu son yıllarda öğretime başlayan havacılık yönetimi programı, 2020-2021 öğretim yılı itibariyle lisans düzeyinde 19 devlet üniversitesinde ve 17 vakıf üniversitesinde faal bir programdır (YÖK Atlas, 2020). YÖK Atlas verilerine göre açılan kontenjan sayıs1 giderek artan havacılık yönetimi programını tercih eden öğrencilerin meslek seçimi bilinç düzeyine ve tercih eğilimlerine yönelik çalışmaların eksikliği mevcut çalışmanın çıkış noktası olmuştur. Havacılık sektörü diğer sektörlere göre daha spesifik çalışma hayatına sahip olduğundan bu mesleğe uygun olmayan kişilerin ilgili programı tercih etmemeleri kaynak israfinın önüne geçmek adına önemlidir. Havacılık sektöründe zamanında performans (on time performance), yabancı dil bilgisinin yeterliliği, mevzuata sıkı sıkıya bağl1lık ve uyumluluk, emniyet yönetim sitemlerinin ve kalite yönetim sistemlerinin gereklilikleri ile vardiyalı çalışma düzeni gibi bir dizi parametre ön plandadır (Gerede, 2016). Yılmaz (2017) yolcu hizmetlerinde vardiyalı çalışanların memnuniyet düzeylerini ölçtüğü çalışmada bu memnuiyet düzeyinin pozitif eğilimli kararsızlık eğiminde olduğunu bulgulamıştır. Kiracı ve Bayrak (2014)'te sivil havacılık lisans mezunlarının bölüm bazında "hayal ettiğim işte çalışıyorum" oranı sivil havacılık ulaştırma işletmeciliği (şimdiki adıyla havacılık yönetimi) bölümünde teknik bölümlere (pilotaj, teknisyenlik vb.) göre en düşük oranda çıkmıştır. Bu da aslında havacılık yönetimi programının bilinçsiz tercih düzeyinin bir yansıması olarak değerlendirilebilir. Yavaş (2021) havacılık yönetimi mezunlarına yönelik iş ilanların ile ilgili analiz çalışmasında iş deneyimi, İngilizce ve temel bilgisayar becerisinin üst sıralarda olduğunu ifade etmiştir.

Sivil havacılık öğrencilerine yönelik 253 öğrenci ile Şen (2019) tarafından yapılan çalışmada anket yöntemiyle ile veriler toplanarak öğrencilerin mesleği bilinçli seçip seçmedikleri araştırılmıştır. Öğrencilerin \%76,7'sinin ilk tercihi havacılık bölümüdür. Havacılığı tercih nedenleri ile ilgili olarak öğrencilerin 7'li Likert skalasına göre puan vermeleri istenmiştir. Buna göre havacılık sektöründe kariyer yapma isteği (6,53 puan), havacıllğın saygın bir meslek olduğunu düşünme (6,52 puan), havacılığa ilgi duyma (6,45 puan), ekip çalışmasını sevme ( 6,18 puan), yeteneklerinin havacılığa uygun olduğunu düşünme $(5,81$ puan) ilk beş sırada yer alan etmenler olmuştur. Anket çalışmalarında öznel tutumlar sonuçlar üzerinde sapma etkisi oluşturabildiğinden, mevcut çalışmada doğrudan YÖK Atlas doküman analiziyle ham tercih verileri üzerinden öğrencilerin mesleki tercih eğilimleri sorgulanmıştır. Tartışma bölümünde doküman analiziyle anket yöntemi, yani mevcut çalışma ile Şen (2019)'in çalışma sonuçları arasındaki farklılıklar ele alınmıştır. Mevcut çalışmanın sonuçları itibariyle hedef kitlesinde havacılık yönetimini tercih eden/edecek öğrenciler, bu 
alanda emek veren öğretim üyeleri ve sivil havacılık sektörü yer almaktadır. Literatürde YÖK Atlas verileriyle lisans düzeyinde farklı programlar için yapılan çalışmalar bulunsa da havacılık yönetimi için bir çalışmanın olmaması ve programla ilgili güncel bir tahlil olmaması çalışmanın bu boşluğu doldurması beklenmektedir. YÖK ATLAS programı verileriyle Bandırma Onyedi Eylül Üniversitesi’ni tercih eden öğrencilerin geldikleri iller sorgulanmış ve üniversitenin yakın çevre ile İstanbul'dan daha çok tercih aldıkları sonucuna varılmıştır (Üzülmez ve Arslan, 2019). Ada (2014) turizm eğitimi veren yükseköğretim kurumları için yaptığı çalışmada, Şimşek vd. (2020) gastronomi ve mutfak sanatları bölümü tercihlerinde Ege Bölgesi örneği konulu çalışmasında yine yakın illerdeki üniversitelerin daha çok tercih edildiğini bulgulamıştır. Ayrıca, YÖK ATLAS programıyla tarih bölümüne yerleşen öğrencilerin giriş sınavında yaptıkları netlerin sayısı ve üniversite tercih sıralamaları ile ilgili bir çalışma mevcuttur (Aktaş ve Aktaş, 2019).

Bu çalışmada öncelikle havacılık yönetimi bölümünün gelişimiyle ilgili bir tarihçe verilmiş olup, havacılık yönetimi mezunlarının iş alanlarına değinilmiştir. Daha sonra havacılık yönetimi bölümünü tercih eden öğrencilerin tercih eğilimleri üzerinden meslek seçim bilinç düzeyi, YKS (Yükseköğretim Kurumları Sınavı) taban puanları ve yaptıkları diğer tercihler üzerinden sorgulanmıştır. Literatürde havacılık yönetimi bölümünü tercih eğilimlerine yönelik yeterli düzeyde çalışmanın olmaması ve ülkemizde havacılık kültürünün yeni yeni oluşmaya başlamasıyla lisans öğrencilerinin bu meslek seçimini yaparken gerçekten bilinçli bir tercih mi yaptıkları yoksa daha çok YKS puanlarını baz alarak mı tercih yaptıkları sorusunun cevabı aranmıştır. Meslek tercihlerinde saygınlık ve statü önemli parametreler olduğundan çalışmada ayrıca havacılık yönetimi bölüm tercihlerinde fakülte ile yükssekokul faktörünün etkisi de alt amaç olarak incelenmek istenmiştir. Mevcut çalışmada toplanan veriler analiz edilirken YKS taban puanlarına göre tercih eğilimleri dikkate alındığında belirgin 2 blok oluştuğu görülmüştür. Yüksek taban puanına sahip fakültede havacılık yönetimine yerleşen öğrencilerin diğer tercihlerinde düşük puanlı sivil havacılık yüksekokul havacılık yönetim programlarını tercih etmek yerine o puan eşdeğerliğinde sınıf öğretmenliği, rehberlik ve psikolojik danışmanlık bölümlerine yöneldikleri görülmüştür. Çalışma kapsamındaki tercih verisi, YÖK ATLAS programından alınan ikincil veriler ile oluşturulmuş olup yöntem bölümünde bu verilerin toplanması ve analizi ilgili konular detaylandırılmıştır.

\section{KAVRAMSAL ÇERÇEVE}

\subsection{Havacılı Yönetimi Bölümü}

Türkiye'de sivil havacılık eğitimi 1986 yılında kurulan Anadolu Üniversitesi Sivil Havacılık Meslek Yüksekokulu ile başlamıştır. İlgili yüksekokulun öğenim süresi, 1992 yılında Yüksek Öğretim Kanununda yapılan değişiklik neticesinde 2 yıldan 4 yıla çıkarılmıştır. Sivil havacılık alanında artan nitelikli personel ihtiyacını karşılamak üzere eski adı "Sivil Hava Ulaştırma İşletmeciliğì" olan havacılık yönetimi bölümü Anadolu Üniversitesinin yanı sıra, 2001 'de Erciyes Üniversitesi, 2005'te Kocaeli Üniversitesi ve 2008'de Mustafa Kemal Üniversitesi lisans düzeyinde öğretim faaliyetlerine başlamıştır (Kiracı ve Bayrak, 2014). Havacılık yönetimi bölüm mezunları, havalimanları, yer hizmetleri, ulusal ve uluslararası hava yolları, ikram ve kargo işletmeleri ve seyahat acenteleri ile diğer havacılık 
işletmelerinde istihdam edilebilmekte; hava yolu pazarlaması, filo planlaması, havacılık emniyeti ve güvenliği, tarife planlama, hava yolu ve havalimanları finansmanı, operasyonel yönetim ve planlama alanlarında görev alabilmektedir (İnan, 2020). Ülkemizde havacılıkta serbestleşme döneminde yani 2003 yılı sonrasında yapılan yasal düzenlemeler ve gerçekleştirilen çalışmalar Türk Sivil Havacılık Sektörünün ivmeli bir şekilde büyümesini sağlamıştır (Kiracı ve Bayrak, 2014). Havacılık sektöründe hızlı büyümeye eş güdümlü olarak sektörde faaliyet gösteren işletmeler, nitelikli insan kaynağı ihtiyacını karşılamak amacıyla üniversite mezunlarının yetersiz düzeyde olması yüzünden bu ihtiyaçlarını kurslar açmak kaydıyla karşılama yoluna gitmişlerdir (Karaağaoğlu, 2015). Her sektörde olduğu gibi havacılık sektöründe de üniversite-sektör ilişkilerinde iş birliğine sağlayan modeller ve projeler her zaman katma değerler yaratmıştır. Kiper (2010), üniversite-sanayi iş birliğini sağlayan ana mekanizmaların beş başlık altında sınıflandırılabileceğini belirtmiştir: Bunlar proje odaklı-kamu destekli iş birliği programları, kamu programlarınca biçimlenen kurumsal iş birliği yapıları, üniversitelerce yürütülen eğitim programları ve sözleşme bazlı projeler, üniversitelerdeki iş birliği amaçlı hizmet merkezleri ve enformel iş birliği ağları ve diğer girişimler şeklindedir. Solvoll ve Hansen (2018) havacılık sektörü ile ve yüksek öğretimde edinilen öğretiler arasında nedensel ilişkiyi sorgulayan bir çalışma yapmışlardır. Çalışmada havalimanlarındaki havacılık hizmetlerini üstlenecek nitelikli insan gücünün yetişmesinde yükseköğrenimin rolüne ve bölgesel gelişim için havacılık sektörünün rolüne değinmişlerdir. Ülkemizde havacılık sektöründe yetişmiş insan gücü ihtiyacının sağlanması amacıyla, Sivil Havacılık Genel Müdürlügü (SHGM) ile Yükseköğretim Kurulu (YÖK) arasında iş birliği protokolü yapılmıştır. YÖK ile SHGM arasında yapılan iş birliği protokolünde, üniversitelerde sivil havacılık sektörü işletmelerinin ihtiyaç duyacağı tüm alanlar ile ilgili bölümlerin açılmasına hükmedilmiştir. Ayrıca kalite standartları gereği bu bölümlere özgü müfredat ve eğitim içeriklerinin oluşturulmasına karar verilmiştir. Protokol kapsamında, üniversitelerde sivil havacılık öğretim programlarının artırılması hedeflenmiş ve Pilotaj, Uçak Bakım Teknisyenliği, Kabin Hizmetleri, Sivil Hava Ulaştırma İşletmeciliği, Havacılık Yönetimi gibi programların artışı hedeflenmiştir (Karaağaoğlu, 2015). Ülkemizde ve dünyada hızla büyüme ivmesi yakalayan sivil havacılık sektörünün iş gücü ihtiyaçlarını karş1layabilecek havacılık kültürüyle yetişmiş ve gerekli mesleki yeterliliklere sahip insan gücünün yetişmesi için üniversitelere büyük iş düşmüştür (Uncular, 2014). Almaz (2020) sivil havacılık alanında 1998-2019 yılları arasında yaptığı lisansüstü tez konularının derlemesi çalışmasında Havacılık Yönetiminin, İşletme ve Yönetim Ana Bilim Dallarıyla iç içe olduğunu vurgulamış ve tezlerinin büyük bir çoğunluğunun Anadolu Üniversitesi bünyesinde tamamlandığı sonucuna varmıştır.

\subsection{Meslek Seçiminde Bilinç}

Yanlış meslek seçimi kişinin yaşamında geri dönülmesi zor olan birtakım sorunları beraberinde getirir. Meslek seçiminde önemli faktörlerden biri de kişide meslek seçimi yeterliliğinin oluşup oluşmadığının incelenmesidir (Vurucu, 2010). Çatı vd. (2016) öğrencilerin üniversite tercihlerini etkileyen faktörleri Türkiye genelinde 1112 öğrenciyle yapılan anket sonucunda sırasıyla saygınlık, imkân, kampus ve sosyallik şeklinde sıralamıştır. Can, Balcı ve Öngel (2013) yaptığı çalışmada kişinin geçmişi, sosyodemografik özellikleri, iş avantajları, yetenekleri, ilgi alanları ve karakter özellikleri gibi 
faktörlerin meslek seçimini etkilediğini bulgulamıştır. Baltacı vd. (2012) turizm eğitimi alan öğrenciler üzerinde yaptıkları çalışmada mezun olan öğrencilerin turizm sektöründen ayrıldıklarını, öğrencilerin \%25'inin bilinçli tercih yaparak yerleştiğini, gelecek kaygısının 3. ve 4. sınıflarda yükseldiğini, erkek öğrencilerde gelecek kaygısının daha fazla olduğu ve aldıkları eğitim memnuiyetinin kız öğrencilerde daha fazla olduğu sonuçlarına ulaşmışlardır. Acar vd. (2010) öğretim elemanlarının öğretim sürecinde karşılaştıkları öğrenci kaynaklı sorunlar arasında bölümü istememesine rağmen tercih edip gelen öğrenciler, bilinçsiz tercih yapan öğrencilerin olduğunu vurgulamaktadır. Bilinçsiz tercihler, lisans öğretiminde etkinliği ve verimliliği düşürüp, öğretim hizmetlerinde motivasyon düşüklüğüne neden olmakta ve öğrenim çıtılarının karşılıksız kalması da kaynak israfına yol açmaktadır. Bilinçli meslek seçimi gerek sektörü gerek öğretim üyelerini gerekse de öğrencileri etkileyen bir parametre olduğundan, üniversite program tercihlerinde öğrencilerin tercih eğilimlerinin ankete göre daha objektif sonuçlar veren YÖK Atlas doküman analiziyle tarama yapılması ve havacılık yönetimi programının güncel durumun tahlili için önemlidir.

\section{YÖNTEM}

\subsection{Verilerin Toplanması}

$\mathrm{Bu}$ çalışmada araştırma modeli olarak belgesel tarama (doküman analizi) seçilmiş ve bilinçlilik düzeyinin ölçülmesinde anket yerine doğrudan 2020 yılına ait YÖK ATLAS YKS tercih ham kayıtları incelenerek öğrencilerin mesleki tercih eğilimleri sorgulanmaya çalışılmıştır. Havacılık yönetimi programının son yıllarda farklı üniversitelerde açılması ve giderek artan kontenjanları ve YKS tercihlerinde öğrencilerin bu bölümün bilinçli tercih edip etmediğini analiz etmek için veri toplanmıştır. Yükseköğretim Kurulu (YÖK) Mart 2016'da üniversite adaylarına bilgi sunmak, tercihlerinde yardımcı olmak amacıyla "Yükseköğretim Program Atlası" (YÖK Atlas), "YÖK Tercih Sihirbazı" ve "YÖK Mezun Atlası" isimli iki yeni modülü eklemiştir. YÖK ATLAS adayların bilinçli tercihlerde bulunmasını sağlamak ve kılavuzdaki şartları ve fırsatları fark etmemeleri nedeniyle yaşanabilecek tercih kazalarını da önlemek gibi amaçlar ile kurulmuştur. YÖK ATLAS lisans programları hakkında genel bilgiler, kontenjan, yerleşme ve kayıt istatistikleri, yerleşenlerin cinsiyet dağılımı, yerleşenlerin geldikleri coğrafi bölgeler, yerleşenlerin geldikleri iller, yerleşenlerin öğrenim durumu, yerleşenlerin liseden mezuniyet yılları, yerleşenlerin mezun oldukları lise alanları, yerleşenlerin mezun oldukları lise grubu/tipleri, yerleşenlerin mezun oldukları liseler, yerleşen okul birincileri, taban puan ve başarı sırası istatistikleri, yerleşen son kişinin profili, yerleşenlerin Yükseköğretim Kurumları Sınavı (YKS) net ortalamaları, yerleşenlerin YKS puanları, yerleşenlerin YKS başarı sıraları, ülke genelinde tercih edilme istatistikleri, yerleşenler ortalama kaçıncı tercihlerine yerleştiği ile yerleşenlerin tercih eğilimleri içerisinde üniversite türleri, üniversiteler, iller, aynı/farklı program, programlar (meslekler), yerleşme koşulları gibi alt başlıklar hakkında bilgiler yer almaktadır (YÖK Atlas, 2020). Bu çalışmada analiz edilen tüm veriler YÖK ATLAS platformundaki havacılık yönetimi lisans düzeyinde örgün eğitim veren devlet üniversitelerine yerleşenlerin tercih eğilimleriprogramlar (meslekler) kısmından alınmıştır. Bu veriler güncel olmakla beraber 2020 yılına aittir. 


\subsection{Verilerin Analizi}

Çalışmada örgün ve devlet üniversitelerinde öğrenim gören lisans öğrencilerinin yaptığ 18693 YKS tercih verisi işlenmiş ve bunların arasında \%0,5'lik dilimin altında kalan az sayıda tercih edilen bölümler "diğer" kategorisinde ele alınmıştır. Türkiye'de 2020 yılı itibariyle havacılık yönetimi lisans kontenjanı sayısı 3133'tür (YÖK Atlas, 2020). İkinci öğretim programı olarak öğretim veren kurumlara yapılan tercih verileri de değerlendirmeye dahil edilmiştir. Çalışmada farklı burs programları seçeneğinin olması nedeniyle vakıf üniversiteleri ve örgün eğitim olmadığı için Açıköğretim İşletme Fakültesi Havacılık Yönetimi tercih verileri ele alınmamıştır. Çalışmada tercih eğilimleriyle ilgili bulgulara geçmeden önce kontenjanların devlet örgün, devlet açık, vakıf, fakülte ve yüksekokul analizleri yapılmıştır. Havacılık yönetimi bölümünde 2020 yılı için mevcut 3133 kontenjan arasında, 2290 kontenjanın (820'si açık öğretim işletme fakültesinde olmak kaydıyla) fakültelerde yer almakta olup, fakülte kontenjanlarının yüksekokul kontenjanlarına (843) göre fazla olduğu bulgulanmıştır (YÖK Atlas, 2020). Şekil 1'de devlet ve vakıf üniversiteleri dahil tüm havacılık yönetimi kontenjanlarının yüksekokul ve fakülte nezdinde dağılım grafiği verilmiştir.

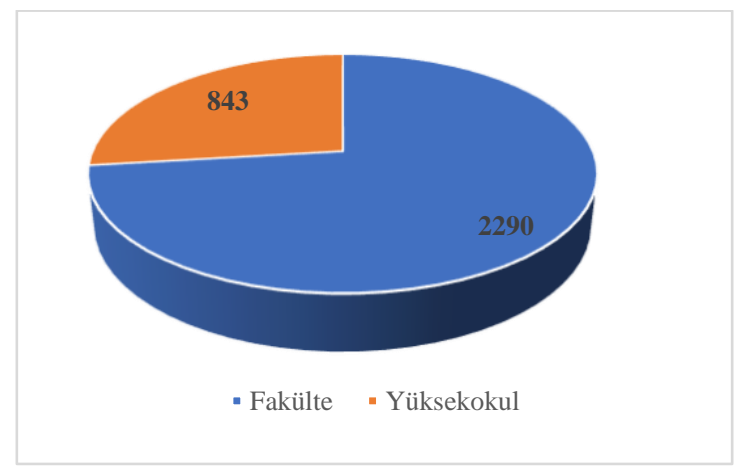

Şekil 1. Havacılık yönetimi bölümünde 3133 lisans kontenjanının fakülte ve yüksekokul nezdinde dağılımları (YÖK Atlas, 2020)

Şekil 2'de havacılık yönetimi bölümünün bağlı olduğu fakültelerde kontenjan dağılımı ile ilgili bir çubuk grafiği sunulmuştur. Havacılık yönetiminin fakülte bazında kontenjan incelemesi yapıldığında 911 kontenjanla İşletme Fakültesi başı çekmektedir. Burada 820 kontenjanla Açıköğretim Fakültesi'nin etkisi büyüktür. İşletme Fakültesini, "Havacılık ve Uzay Bilimleri Fakültesi” 783 kontenjanla takip etmektedir. Bu tür fakültelerde havacılık yönetimi programı, genelde uçak gövde motor bakım, havacılık elektrik elektroniği, uçak mühendisliği gibi teknik programlar ile beraberdir. Bunun yanı sıra havacılık yönetimi programı, teknik bölümlerin olanaklar dahilinde açılamadığı, yeni açılan devlet üniversiteleri ile vakıf üniversitelerinde iktisadi ve idari bilimler, iktisadi, idari ve sosyal bilimler fakültelerinin alt programı olarak açılmaktadır. 


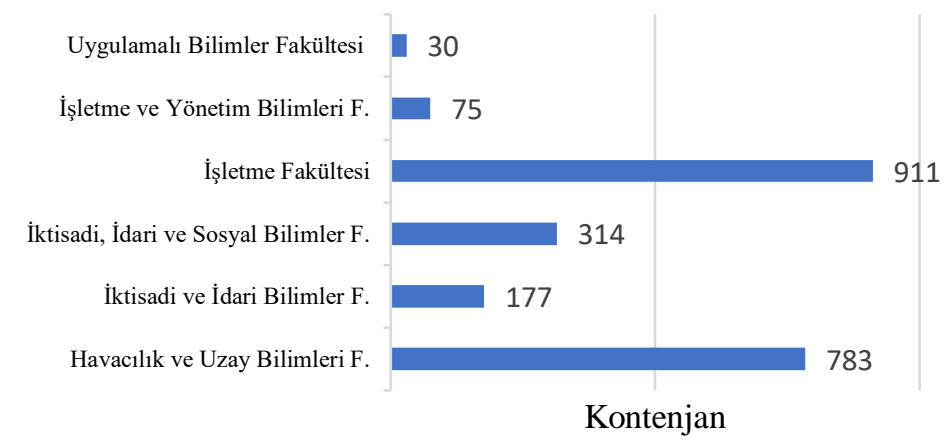

Şekil 2. Havacılık yönetimi bölümünün bağlı olduğu fakültelerde 2290 lisans kontenjanının dağılımı (YÖK Atlas, 2020)

Şekil 3'te havacılık yönetimi bölümünün bağlı olduğu yüksekokullarda 843 lisans kontenjan dağılımı verilmiştir. "Sivil Havacılık Yüksekokuluna" (SHYO) bağlı havacılık yönetimi Programı 672 kişilik lisans kontenjana sahipken, "Uygulamalı Bilimler Yüksekokulu” adı altında havacılık yönetimi bölümünün 171 kontenjanı vardır. Gümüşhane Üniversitesi, Kapadokya Üniversitesi ve İstanbul Gelişim Üniversitesi'nde havacılık yönetimi programı Uygulamalı Bilimler Yüksekokuluna bağlı olarak öğretim faaliyetlerini sürdürmektedir (YÖK Atlas, 2020).

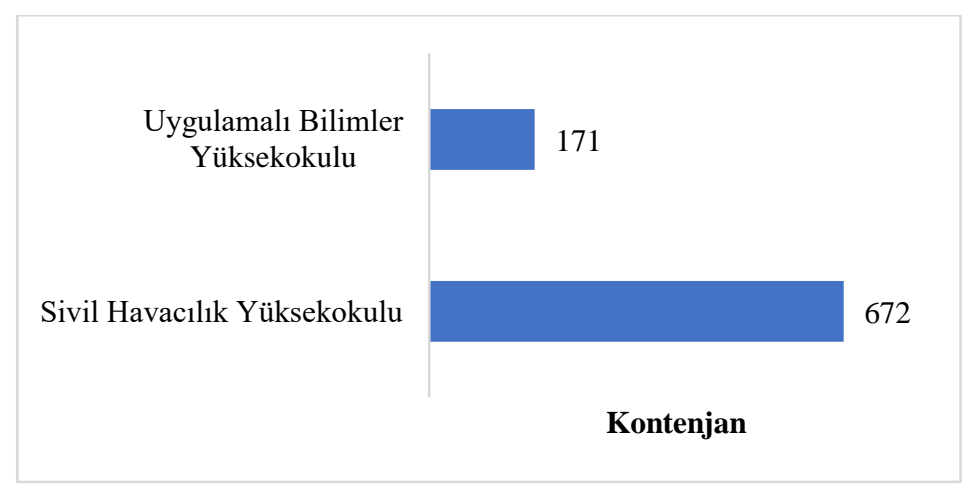

Şekil 3. Havacılık yönetimi bölümünün bağlı olduğu yüksekokullarda fakültelerde 843 lisans kontenjanının dağılımı (YÖK Atlas, 2020)

Havacılık yönetimi bölümünün 3133 lisans kontenjanının devlet ve vakıf üniversitelerinde kontenjan dağılımları örgün ve açı öğretim detayıyla beraber Şekil 4'te çubuk grafiğinde verilmiştir. Bu veriler ışığında, vakıf üniversitelerinde \%27,5 oranında bir kontenjan varlığından bahsedilebilir. 


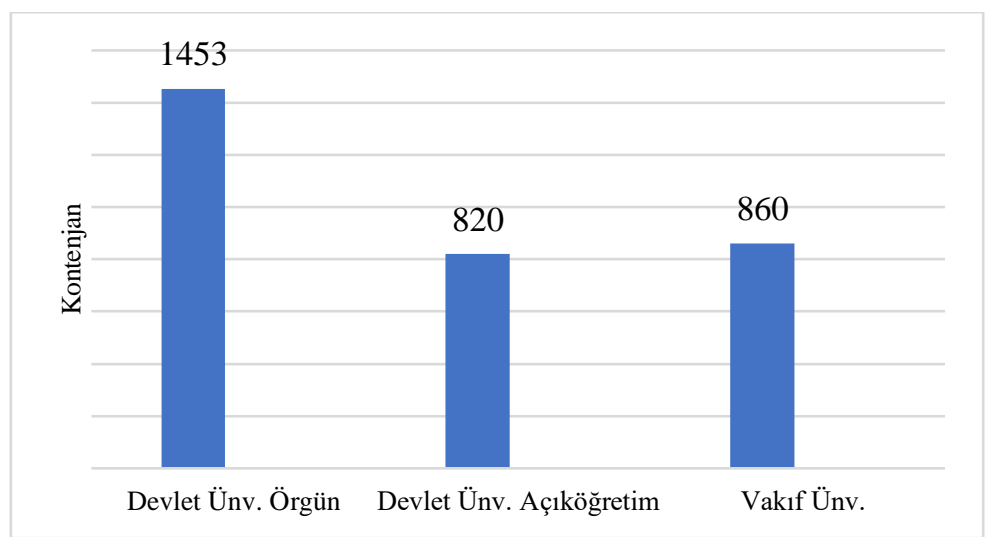

Şekil 4. Devlet ve vakıf üniversitelerinde kontenjan dağılımı (YÖK Atlas, 2020)

\section{BULGULAR}

YÖK Atlas 2020 çevrimiçi doküman arşivinden 18693 tercih verisiyle yapılan çalışmanın toplu sonuçları Tablo 1'de verilmiştir. Fakülte ve yüksekokul nezdinde toplamda \%37,24'lük bir oranla havacılık yönetimi programı tercih edilmiştir. Diğer tercihlerin yüzdelik payı \%14,65 iken; sınıf öğretmenliği, yönetim bilişim sistemleri, rehberlik ve psikolojik danışmanlık, psikoloji, sağlık yönetimi, sosyal hizmet, işletme, uluslararası ilişkiler, Türkçe öğretmenliği ve sosyal bilgiler öğretmenliği gibi tercihler havacılık sektörüyle bağlantısı olmayan tercihler olarak hatırı sayılır oranlarda tercih sayısına ulaşan bölümler olarak rapor edilmiştir. 18693 tercih verisi arasında tabloda başı çeken bölümler incelendiği zaman ilk üç sırada yer alan bölümler ve sayısal verileri şu şekildedir: Birinci ve başı çeken bölüm 1634 tercih sayısıyla sınıf öğretmenliği \%8,74 oranla gelmektedir. İkinci sırada 959 tercih sayısıyla yönetim bilişim sistemleri \%5,13 oranla gelmektedir. Üçüncü sırada 772 tercih sayısıyla rehberlik ve psikolojik danışmanlık bölümü $\% 4,13$ oranla yer almaktadir.

Çalışma sonuçlarında havacılık yönetiminin fakülte ve yüksekokul nezdinde toplamda tercih edilme yüzdelerinin tekil verilerine göre 2 bloğun oluştuğu gözlemlenmiştir. 1. Blok dengesiz tercih diyebileceğimiz genelde fakültelerden oluşan ve görece yüksek YKS taban puanına sahip üniversitelerin havacılık yönetimi programıdır. 2. Blok dengeli tercih diyebileceğimiz genelde SHYO'dan oluşan ve görece daha düşük YKS taban puanına sahip üniversitelerin havacılık yönetimi programıdır. 1. Blokta yer alan üniversitelerin havacılık bölümü programına yerleşen öğrencilerin havacılık yönetimi tercih yüzdeleri Tablo 2'de verilmiştir: Eskişehir Teknik Üniversitesi \%20,0, Kocaeli Üniversitesi \%21,8, Erciyes Üniversitesi \%27,9, Alanya Alaaddin Keykubat Üniversitesi \%30,2 ve Gaziantep Üniversitesi \%29,0. 
Tablo 1. 18693 YKS tercih verisinin dağılım yüzdesi

\begin{tabular}{|l|c|c|}
\hline BÖLÜM & TERCIH Sayısı & \%'lik Payı \\
\hline Havacılık Yönetimi (Fakülte/Yüksekokul) & 6962 & 37.24 \\
\hline Diğer & 2738 & 14.65 \\
\hline Sınıf Öğretmenliği & 1634 & 8.74 \\
\hline Yönetim Bilişim Sistemleri & 959 & 5.13 \\
\hline Rehberlik ve Psikolojik Danışmanlık & 772 & 4.13 \\
\hline Psikoloji & 625 & 3.34 \\
\hline Sağlık Yönetimi & 624 & 3.34 \\
\hline Sosyal Hizmet & 457 & 2.44 \\
\hline İşletme & 455 & 2.43 \\
\hline Uluslararası İlişkiler & 449 & 2.40 \\
\hline Türkçe Öğretmenliği & 393 & 2.10 \\
\hline Sosyal Bilgiler Öğretmenliği & 358 & 1.92 \\
\hline Siyaset Bilimi ve Kamu Yönetimi & 296 & 1.58 \\
\hline Denizcilik İşletmeleri Yönetimi & 249 & 1.33 \\
\hline Maliye & 233 & 1.25 \\
\hline İç Mimarlık ve Çevre Tasarımı & 232 & 1.24 \\
\hline Çocuk Gelişimi & 227 & 1.21 \\
\hline İktisat & 224 & 1.20 \\
\hline Gastronomi ve Mutfak Sanatları & 214 & 1.14 \\
\hline Uluslararası Ticaret ve Lojistik & 166 & 0.89 \\
\hline Sosyoloji & 155 & 0.83 \\
\hline Okul Öncesi Öğretmenliği & 154 & 0.63 \\
\hline Türk Dili ve Edebiyatı & 117 & \\
\hline
\end{tabular}

2. blokta yer alan üniversitelerin havacılık bölümü programına yerleşen öğrencilerin havacılık yönetimi tercih yüzdeleri Tablo 3'te verilmiştir: Necmettin Erbakan Üniversitesi \%41,1, Balıkesir Üniversitesi \%41,5, Amasya Üniversitesi \%39,4, Iğdır Üniversitesi \%35,5, İskenderun Teknik Üniversitesi \%43,0, Erzincan Binali Yıldırım Üniversitesi \%39,7, Gümüşhane Üniversitesi \%39,7, Kastamonu Üniversitesi \%39,8, Muğla Sitk1 Koçman Üniversitesi \%39,8, Samsun Üniversitesi \%36,8, Selçuk Üniversitesi \%43,6, Süleyman Demirel Üniversitesi \%41,0.

Tablo 2 ve Tablo 3'te, Tablo 1'den elde edilen ve tüm tercih datalarında üst kısımlarda yer alan 11 programın, söz konusu üniversiteler bazında yüzdelik tercih değerlendirilmesi verilmiştir. 
Tablo 2. 1. Bloktaki üniversitelere yerleşen havacılık yönetimi öğrencilerinin tercih dağılımlarının gösterimi. YKS taban puanları parantez içinde verilmiştir.

\begin{tabular}{|l|c|c|c|c|c|}
\hline & $\begin{array}{c}\text { Eskişehir Tek. } \\
\text { Üniv. (355.7) }\end{array}$ & $\begin{array}{c}\text { Kocaeli Üniv. } \\
\mathbf{( 3 3 7 . 3 )}\end{array}$ & $\begin{array}{c}\text { Erciyes Üniv } \\
\mathbf{( 3 2 8 . 6 )}\end{array}$ & $\begin{array}{c}\text { Alanya A.K. } \\
\text { Üniv. (307.1) }\end{array}$ & $\begin{array}{c}\text { Gaziantep } \\
\text { Üniv. (305.5) }\end{array}$ \\
\hline Havacılık Yönetimi (Fakülte) & 18.6 & 20.3 & 24 & 19.9 & 21.6 \\
\hline Havacılı̈ Yönetimi (YO) & - & - & 3.9 & 10.3 & 7.4 \\
\hline Sinı̈ Öğr. & 16.1 & 28.1 & 35.8 & 9.3 & 23.7 \\
\hline Yönetim Bilişim Sistemleri & 2 & 4 & 5.5 & 7.9 & - \\
\hline $\begin{array}{l}\text { Rehberlik Psikolojik } \\
\text { Danışmanlık }\end{array}$ & 16.2 & 16.2 & 12.1 & 4.2 & 8.4 \\
\hline Psikoloji & 9.1 & 4.2 & 3.6 & 4.3 & 2.4 \\
\hline Sağlık Yönetimi & - & - & - & 3 & - \\
\hline Sosyal Hizmet & 0.9 & 1.5 & - & 3 & 0.9 \\
\hline İșletme & 6.2 & 4.1 & 1.6 & 3 & 2.4 \\
\hline Uluslararası İlişkiler & 3.2 & 4.2 & 0 & 2.6 & 1.4 \\
\hline Türkçe Öğr. & - & 1.2 & 2.2 & 6.7 & 5 \\
\hline Sosyal Bilgiler Ö̆ğr. & - & - & - & 1.7 & 1.4 \\
\hline $\begin{array}{l}\text { Siyaset Bilimi ve Kamu } \\
\text { Yönetimi }\end{array}$ & 2.8 & 2.1 & - & 1.9 & 1.1 \\
\hline
\end{tabular}

YKS taban puanı en yüksek Eskişehir Teknik Üniversitesi (355.7), Kocaeli Üniversitesi (337.3) Erciyes Üniversitesi (328.6) ile Alanya Alaaddin Keykubat Üniversitesi (307.1) ve Gaziantep Üniversitesi (305.5) havacılık yönetimi programına yerleşen öğrencilerin tercihleri dengesiz tercih eğilimi bloğunda yani 1. Bloktadır. Eskişehir Teknik Üniversitesi havacılık yönetimine yerleşen öğrencilerin \%16,2 oranında rehberlik ve psikolojik danışmanlık tercihi bulunmakta ve $\% 16,1$ oranında sınıf öğretmenliği tercihi bulunmaktadır. Erciyes Üniversitesi havacılık yönetimine yerleşen öğrencilerin \%35,8 oranında sınıf öğretmenliği tercihi bulunmakta ve $\% 12,1$ oranında rehberlik ve psikolojik danışmanlık tercihi bulunmaktadır. Kocaeli Üniversitesi havacılık yönetimine yerleşen öğrencilerin sınıf öğretmenliği \%28,1, rehberlik ve psikolojik danışmanlık \%16,2 oranındadır. Gaziantep Üniversitesi havacılık yönetimine yerleşen öğrencilerin \%23,7 oranında sınıf öğretmenliğ tercihinde bulunurken \%8,4 oranında rehberlik ve psikolojik danışmanlık tercihinde bulunmuştur. Genel bir değerlendirme yapmak gerekirse görece yüksek YKS taban puanıyla yerleşen havacılık yönetimi bölümü öğrencilerinin eğilimli oldukları meslekler genelde havacılık dışı programlardır. Dolayısıyla 1. bloktaki üniversitelerde, havacılık yönetiminin yüksek bilinç düzeyinden bahsetmek olanaksızdır. Bu tezi Tablo 2'nin ikinci satırından yer alan sivil havacılık yüksekokul (SHYO) tercih oranlarının çok düşük olması da desteklemektedir. $\mathrm{Bu}$ öğrenciler kolayca SHYO havacılık yönetimi programlarına yerleşebilecekken YKS puanlarına yakın sınıf öğretmenliği, rehberlik ve psikolojik danışmanlık gibi bölümleri tercih etmişlerdir. Havacılık yönetiminden sonra en çok tercih edilen sınıf öğretmenliğinin YKS üniversiteler bazında taban puan aralığı 344.6- 382.7, yönetim bilişim sistemlerinin üniversiteler bazında taban puan aralığ $1228.9-486.5$; rehberlik ve psikolojik danışmanlığın üniversiteler bazında taban puan aralığ1 335.3-446.9, psikolojinin üniversiteler bazında taban puan aralığı 324.7-492.9 ve sağlık yönetiminin üniversiteler bazında taban puan aralığ1 191.4-321.4'dir. Bu veriler yüksek YKS puanıyla tercih yapan öğrencilerin (Tablo 2'de verilen 1. bloktaki üniversitelerde) tercihlerinde daha 
çok YKS puanını baz aldıkları tezini güçlendirmektedir. Bu blokta havacılık yönetimi bölümünün eğilimli mesleklerin yanında "yedek tercih" olarak seçildiği sonuç olarak söylenebilir; çünkü sınıf öğretmenliği, yönetim bilişim sistemleri, rehberlik ve psikolojik danışmanlık bölümleri gibi programların havacılık yönetimi bölümü puanlarına çok yakın sayılabilecek seviyededir.

Tablo 3. 2. Bloktaki üniversitelere yerleşen havacılık yönetimi öğrencilerinin tercih dağılımlarının gösterimi. YKS taban puanları parantez içinde verilmiştir.

\begin{tabular}{|c|c|c|c|c|c|}
\hline & $\begin{array}{l}\text { Necmettin } \\
\text { Erbakan Üniv. } \\
(310.4)\end{array}$ & $\begin{array}{l}\text { Balıkesir } \\
\text { Üniv. } \\
\text { (298.8) }\end{array}$ & $\begin{array}{c}\text { İskenderun } \\
\text { Teknik Üniv. } \\
\text { (291.0) }\end{array}$ & $\begin{array}{c}\text { Kastamonu } \\
\text { Üniv. (283.6) }\end{array}$ & $\begin{array}{c}\text { Erzincan } \\
\text { B.Y. Üniv. } \\
(262.5)\end{array}$ \\
\hline Havacılık Yönetimi (Fakülte) & 28.9 & 27.9 & 18.4 & 16.8 & 13 \\
\hline Havacılık Yönetimi (YO) & 12.2 & 15.1 & 23.1 & 22.8 & 26.8 \\
\hline Sınıf Öğretmenliği. & 14 & 4.5 & 4 & 1.2 & - \\
\hline Yönetim Bilişim Sistemleri & 3.3 & 5.5 & 6.8 & 4.9 & 3.1 \\
\hline $\begin{array}{l}\text { Rehberlik Psikolojik } \\
\text { Danışmanlık } \\
\end{array}$ & 4.3 & 2.4 & 1 & 1.1 & 0.6 \\
\hline Psikoloji & 2.7 & 2 & 2.6 & 1.5 & 1.4 \\
\hline Sağlik Yönetimi & 2.9 & 1.7 & $\underline{6}$ & $\underline{8.3}$ & $\underline{8.1}$ \\
\hline Sosyal Hizmet & 3 & 1.9 & 1.8 & 4.8 & 3.7 \\
\hline İşletme & 2.3 & 2 & 4.7 & 1.1 & 1.2 \\
\hline Uluslararası İlişkiler & 2.4 & 1.2 & 1.8 & 1 & $\underline{4.3}$ \\
\hline Türkçe Öğretmenliği & - & $\underline{5.1}$ & 2.7 & 1.2 & 2 \\
\hline Sosyal Bilgiler Öğretmenliği & - & $\underline{3.9}$ & 2.1 & 2.7 & $\underline{5.5}$ \\
\hline $\begin{array}{l}\text { Siyaset Bilimi ve Kamu } \\
\text { Yönetimi }\end{array}$ & - & 0.7 & 1.2 & 2.6 & 2.1 \\
\hline
\end{tabular}

Tablo 3'te havacılık yönetimi bölümüne yerleşen öğrencilerin dengeli tercih dağılımına sahip olduğu üniversitelerden birkaçının tercih dağılımı verilmiştir. YKS taban puanına göre daha düşük taban puanlarına sahip ikinci bloktaki üniversitelerin çoğu SHYO’dur. YKS taban puanları: Necmettin Erbakan Üniversitesi 310.4, Balıkesir Üniversitesi 298.8, İskenderun Teknik Üniversitesi 291.0, Kastamonu Üniversitesi 283.6, ve Erzincan Binali Yıldırım Üniversitesi 262.5'tir. Necmettin Erbakan Üniversitesi'nde havacıllk yönetimine yerleşen öğrenciler \%28,9 oranında fakülte tercih ederken \%12,2 oranında SHYO tercih etmişlerdir. Dengeli tercihler bloğunda yer alan üniversitelerden İskenderun Teknik Üniversitesi \%27,9 oranında Havacılık Fakültesi, \%15,1 oranında SHYO tercih edilmiştir. Edremit SHYO da \%23,1 oranında Havacılık Fakültesi \%18,4 oranında SHYO tercih edilmiştir. Erzincan Ali Cavit Çelebioğlu SHYO ise \%22,8 oranında yüksekokul, \%16,8 oranında Havacılık Fakültesi tercihi bulunmaktadır. Havacılık yönetimi dışında eğilimi olunan mesleklerin verileri şu şekildedir sınıf öğretmenliği \% \% 9,3 , yönetim bilişim sistemleri $\% 7,9$, rehberlik ve psikolojik danışmanlık \%4,2'dir. 


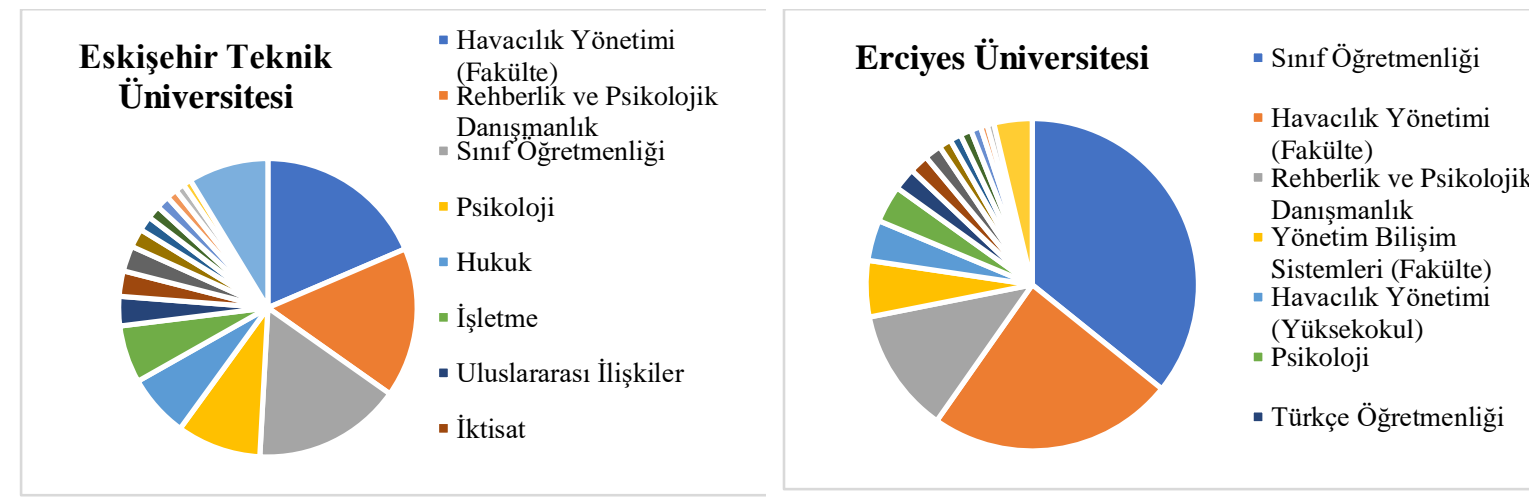

Şekil 5. 1. Bloktaki üniversitelere yerleşen öğrencilerin tercih dağglımının pasta grafiğgi

Şekil 5 'te 1. Bloktaki dengesiz tercih dağllımına giren 2 üniversitenin tercih verileri pasta grafiği şeklinde verilmiştir. Bu tercihlerde SHYO tercihi olmaması, tercihlerde YKS puanın mesleki bilincin önünde olduğu iddiasını güçlendirmektedir. İlgili blokta sınıf öğretmenliği ve rehberlik ve psikolojik danışmanlık tercihleri ön plandadır. ESTÜ'de SHYO tercihi \%0 iken Erciyes Üniversitesi’nde \%3,9 oranında kalmıştır.

\begin{tabular}{|c|c|c|c|}
\hline $\begin{array}{c}\text { İskenderun Teknik } \\
\text { Üniversitesi }\end{array}$ & $\begin{array}{l}\text { - Havacilık Yönetimi } \\
\text { (Fakülte) } \\
\text { - Havacillk Yönetimi } \\
\text { (Yüksekokul) } \\
\text { - Yönetim Bilişim Sistemle } \\
\text { (Fakülte) } \\
\text { - Türkçe Ögretmenliği } \\
\text { - Sınıf Öğretmenliği } \\
\text { - Sosyal Bilgiler } \\
\text { Öğretmennliği } \\
\text { - Denizcilik lşletmeleri } \\
\text { Yönetimi } \\
\text { - Rehberlik ve Psikolojik } \\
\text { Danışmanlık }\end{array}$ & $\begin{array}{l}\text { Kastamonu } \\
\text { Üniversitesi }\end{array}$ & $\begin{array}{l}\text { - Havacılık Yönetimi } \\
\text { (Yüksekokul) } \\
\text { - Havacılık Yönetimi } \\
\text { (Fakülte) } \\
\text { - Sağlık Yönetimi (Fakülte } \\
\text { - Sosyal Bilgiler Öğretmen } \\
\text { - Uluslararası İlişskiler } \\
\text { - Sosyal Hizmet (Fakülte) } \\
\text { - Yönetim Bilişim Sistemle } \\
\text { - Fakülte) } \\
\text { - Siyaset Bilimi ve Kamu } \\
\text { Yönetimi }\end{array}$ \\
\hline
\end{tabular}

Şekil 6. 2. Bloktaki üniversitelere yerleşen öğrencilerin tercih dağılımının pasta grafiğgi

Şekil 6'da 2. bloktaki üniversitelere yerleşen öğrencilerin tercih dağılımları verilmiştir. Ağırlıklı olarak SHYO bloğunun bulunduğu görece düşük YKS taban puanıyla tercih edilen bölümlerde fakülte tercihlerinin yüksek olması ve yüksekokul tercihleri birleştirdiğinde yaklaşık olarak \%40 civarında bir havacılık yönetimi programının tercih edildiği söylenebilir. Bu oranın yüksek çıkmasında şüphesiz alternatif mesleklerin sayıca az olması önemli bir etken olarak önümüze çıkmaktadır. Yani görece düşük YKS puanı olan öğrenciler düşük puanlar ile tercih alan üniversitelerin sağlık yönetimi, sosyal hizmet gibi bölümlerini tercih etmek istemezken (Tablo 3) görece yüksek YKS taban puanına sahip öğrenciler sınıf öğretmenliği ve rehberlik ve psikolojik danışmanlık gibi meslekleri yüksek oranda tercih etmişlerdir (Tablo 2).

\section{TARTIŞMA VE SONUÇ}

Mevcut çalışmada "Yükseköğretim Program Atlası" (YÖK Atlas) 2020 verileri kullanılarak örgün eğitim veren devlet üniversitelerinde havacılık yönetimi programına yerleşen öğrencilerin meslek seçimi ve tercih eğilimleri hakkında analizler yapılmıştır. Öğrencilerin 18693 tercih datası incelendiğinde YKS puanlarının meslek seçimindeki etkisinin baskın 
olduğu oluşan bloklardan açıkça görülmektedir. Tercih puanının meslek tercihinin önünde geçmesi öğrencilerde meslek seçim bilincinin oluşmadığını göstermektedir. Daha detaylı açıklamak gerekirse, görece yüksek YKS taban puanıyla havacılık yönetimi programına yerleşen öğrencilerin sınıf öğretmenliği, yönetim bilişim sistemleri ile rehberlik ve psikolojik danışmanlık gibi bölümleri tercih edip SHYO’lardaki havacılık yönetimi programını tercih etmemeleri çalışmanın en önemli bulgusudur. Görece yüksek YKS taban puanı olan 1. Blok havacılık yönetiminin tercih oranları \%20 bandındayken; görece düşük YKS taban puanı olan 2. Blok havacılık yönetiminin tercih oranları $\% 40$ bandındadır. Tablo 1 'de verilen toplam oranın \%37,24 olmasında SHYO kontenjanlarının örgün öğrenim veren fakülte kontenjanlarına göre nispeten sayıca fazla olmasıdır. Görece düşük YKS taban puanı olan öğrenciler sağlık yönetimi, sosyal hizmet gibi bölümlerinin düşük taban puanına sahip üniversitelerdeki söz konusu bölümleri tercih etmek istemezken yüksek oranda fakültelerdeki havacılık yönetimi bölümü tercihi yapmışlardır. Görece düşük YKS puanların öğrencilerin cazip alternatif mesleklerin olmayışı bütün tercih oranlarının \%37,24 çıkmasını sağlamıştır. Bu çıkarımı tüm oranları \%37,24 iken 1. Blokta yani iyi alternatifler oluştuğunda havacılık yönetimi tercihlerinin yaklaşık \%20 skalasında kalması göstermektedir.

Şen (2019) tarafindan anket çalışmasıyla yapılan havacılık bölümlerine yerleşen öğrencilerin meslek seçiminde etkili olan faktörlerin incelenmesi konulu çalışmada yüksek oranda $(\% 76,7)$ havacılık bölümlerinin ilk tercihi olduğu verisi, öğrencilerde bilinçlilik düzeyinin yüksek olduğunu ifade etse de mevcut çalışmada YÖK ATLAS doküman analiziyle elde edilen bulgularda, öğrencilerde bilinçlilik düzeyinin yüksek olmadığ1 sonucuna varılmıştır. Bu da anket yönteminde sübjektif tutumların sonuçlar üzerinde etkili olduğunu göstermektedir. Literatürde yapılan araştırmalarda öğrencilerin tercih eğilimlerini etkileyen en temel faktörlerin YKS taban puan baz alınarak tercih yapılması, statü faktörü, rehberlik hizmeti (kariyer merkezleri) etkisi, aile ve arkadaş çevresinin yönlendirmesi, sosyal medya faktörü ile iş bulma kaygıları olduğu bulunmuştur. Bu faktörlerden YKS taban puan baz alınarak tercih yapılması ile statü faktörü çalışma sonuçlarıyla bağlam ilişkileri kurulabilen faktörlerdir. Erkuş vd. (2020) öğrencilerin bölüm tercihini etkileyen faktörler arasında sınav puanı ve iş bulmanın ağırlık faktör olduğunu bulgulamıştır. Özellikle tercihlerde çoğu öğrencinin bir önceki senelerde taban puanları baz alarak tercih yapması sınav puanının tercihler üzerindeki etkisinin artışını tetiklemektedir. Yüksek YKS puanına sahip öğrencilerde havacılık yönetimi tercih oranının \%20'lerde; düşük YKS puanına sahip öğrencilerde havacılık yönetimi tercih oranının \%40'larda çıkması, taban puanının bilinçli meslek seçiminden daha etkili olduğu anlamına gelmektedir. Statü faktöründe, daha iyi bir pozisyon, yüksek maaş ve toplumda saygınlığı olan meslek tercihi ön plandadır. Gizden (2020) lise son sınıf öğrencilerinin meslek seçiminde öğrenci tercihlerini ağırlıklı olarak etkileyen parametrenin statü olduğunu vurgulamıştır. Meslekten elde edilen gelir ve kariyer imkânları meslek seçimini etkileyen önemli etmenler arasındadır (Pekkaya ve Çolak, 2013). Mevcut çalışmada fakültelerde havacılık yönetimi programına yerleşen öğrencilerin SHYO havacılık yönetimi tercihi yapmaması benzer öğretim müfredatlarına sahip olmalarına rağmen fakültelerin, yüksekokullara göre öğrencilerdeki saygınlık algısının (statünün), meslek tercih bilincinin önüne geçtiği şeklinde yorumlanabilir. Çalışmada meslek seçimi bilinçlilik düzeyinin doğrudan havacılık yönetimi ham tercih verileriyle ölçüldüğünden 
çalışma sonuçlarıyla rehberlik hizmeti (kariyer merkezleri) etkisi, aile ve arkadaş çevresinin yönlendirmesi, sosyal medya faktörü ile iş bulma kaygılarının etkileriyle bağlam ilişkisi kurulamamıştır. Cevher (2015) büro yönetimi ve yönetici asistanlığı programı için bilinçli tercih oranının \%26 civarında olduğunu belirlemiştir. Öğrencilere yönelik kariyer yönlendirmede eksikliklerin ve rehberlik hizmetlerinin yetersizliğine çözüm olarak kariyer merkezlerini sayıca artırılması gerektiğini savunulmaktadır. Şeker ve Kaya (2018) meslek seçiminde ailenin rolünü bilgilendirme, kabul ve cesaretlendirme boyutları üzerinden geliştirdikleri bir ölçek ile ölçmüşlerdir. Öğrenciler tercihler ile ilgili cevabını bulamadığı sorular için genelde sosyal medyayı kullanmaktadır. Yörükoğlu (2010) sosyal medyada oluşturulan öğrenci sayfalarına yazılan olumlu ve olumsuz yorumların meslek ve program seçimini etkilediğini bulgulamıştır. Sayın (2019) sayıca giderek artan üniversite bölüm kontenjanların öğrenci tercihlerindeki değişimi üzerine bir derleme çalışma yapmıştır. Söz konusu çalışmada 2018 yılında 589.258 lisans öğrencisinin ikinci bir bölüm okuduğu ve iş bulma kaygısının meslek tercihinde önemli bir faktör olduğunu ifade edilmiştir. Üniversite kontenjanlarındaki artışa rağmen yeterli düzeyde istihdamın sağlanmaması neticesinde artan işsizlik oranlarındaki artış, iş bulma kaygısının meslek tercihlerindeki etkisini de güçlendirmektedir.

Çalışmanın kısıtı, bilinçlilik düzeyinin doğrudan havacılık yönetimi ham tercih verileriyle ölçülmesidir. Bilinçlilik düzeyinin öğrencide mi yüksek olduğu yoksa öğrencinin havacılık yönetimi program tercihlerini rehber yönlendirmesi, aile yönlendirmesi, sosyal medya yönlendirmesi ile yaptığ mevcut çalışmada kullanılan yöntemle ölçülemez. Zaten çalışmanın birincil amacının öğrencilerdeki bilinçlilik düzeyinin değil de öğrencilerin tercih eğimlilerini incelenmesi olduğundan, bu kısıtın çalışmanın değerini etkilemediği söylenebilir. Mevcut çalışmadaki veriler 2020 verisi olup önümüzdeki yıllarda yayınlanacak dokümanlar analiz edilip tercih eğilimlerinin ne yönde değişeceği gelecekte araştırılabilir. 


\section{KAYNAKÇA}

Acar, F. E., Kılıç, A., Ay, Ş., Vardar, A. K., \& Kara, R. (2010). Öğretim elemanlarının pedagojik formasyon ihtiyac1. In International Conference on New Trends in Education and Their Implications (pp. 11-13).

Ada, Ç. (2014). Lisans Düzeyinde Turizm Eğitimi Veren Yükseköğretim Kurumlarının Durumu: Yökatlas Veritabanı İncelemesi. (Yayınlanmamış Yüksek Lisans Tezi). Mersin Üniversitesi, Turizm İşletmeciliği Ana Bilim Dalı, Mersin.

Aktaş, Ö., \& Aktaş, D. (2018). Yök Atlas (2018) Verilerine Göre Tarih Bölümlerinin Ve Tarih Öğretmenliği Programlarının Değerlendirilmesi. Turkish History Education Journal, 8(2), 476-498.

Baltac1, F., Üngüren, E., Avsallı, H., ve Demirel, O. N. (2012). Turizm eğitimi alan öğrencilerin eğitim memnuniyetlerinin ve geleceğe yönelik bakış açıların belirlemesine yönelik bir araştırma. Uluslararası Alanya Işletme Fakültesi Dergisi, 4(1), 17-25.

Can, H., Balcı, U. G., Öngel, K. (2013). İzmir Kâtip Çelebi Üniversitesi Tıp Fakültesi birinci sınıf öğrencilerinin meslek seçiminde etkili faktörler. Eurasian Journal of Family Medicine, 2(2), 77-82.

Cevher, E. (2015). Büro Yönetimi ve Yönetici Asistanlığı Programı Öğrencilerinin Bireysel Kariyer Amaçlarının Belirlenmesine Yönelik Bir Araştırma. Yükseköğretim ve Bilim Dergisi, 8(2), 196-202.

Çatı, K., İştar, E., ve Özcan, H. (2016). Üniversite Tercihlerine Etki Eden Faktörlerin İncelenmesi: Türkiye Genelinde Bir Alan Araştırması. Journal of Higher Education \& Science/Yüksekögretim ve Bilim Dergisi, 6(2).

Erkuş, H., Tolga, O. Ve Sever, S. Üniversite Öğrencilerinin Bölüm Tercihlerini Etkileyen Faktörler Üzerine Bir Araştırma. Dicle Üniversitesi Ikktisadi ve İdari Bilimler Fakültesi Dergisi, 10(20), 261-275.

Gerede, E. (2016). Havacılık Emniyeti. TC Anadolu Üniversitesi Yayınları.

Gizden, P. (2020). Lise son sinıf ögrencilerinin üniversite tercihleri üzerinde statü olgusunun etkisi: Avcılar örneği (Master's thesis, Maltepe Üniversitesi, Lisansüstü Eğitim Enstitüsü).

Inan, T. T. (2020). Sivil havacılıkta güncel konular: Sivil havacılık tarihi ve değişen trendler. Hiperlink eğit. Ilet. Yay. san. tic. ve ltd. sti.

Karaağaoğlu, N. (2015). Sivil havacılık alanındaki sektör beklentileri ve istihdam taleplerinin akademik programların oluşturulmasında etkisi: YÖK-SHGM Sivil Havacılık Ĕ̈itim Komisyonu çalışmaları (Master's thesis, Maltepe Üniversitesi, Sosyal Bilimler Enstitüsü).

Kiper, M. (2010). Dünyada ve Türkiye'de üniversite-sanayi işbirliği.1. Baskı. Ankara: İşkur Matbaacilık.

Kiracı, A. G. K., Bayrak, A. G. Ü. (2014). Sivil Havacılık Lisans Mezunlarının İstihdam ve Kariyer Durumları Üzerine Bir Araştırma/A Study of Civil Aviation Graduates' Employment and Career Status. e-Uluslararası Eğitim Araştırmaları Dergisi, 5(2), 68-88.

Pekkaya, M., Çolak, N. (2013). Üniversite öğrencilerinin meslek seçimini etkileyen 
faktörlerin önem derecelerinin AHP ile belirlenmesi. The Journal of Academic Social Science Studies, 6(2), 797-818.

Sayın, Z. (2019). Öğrenci Tercihlerinde Değişim. İlke Politika Notu 11. Erişim Tarihi: 5 Haziran 2021 https://ilke.org.tr/ogrenci-tercihlerinde-degisim

Şen, G. (2019). Üniversitede Havacılık Bölümlerinde Okuyan Öğrencilerin Meslek Seçiminde Etkili Olan Faktörlerin İncelenmesi. Journal of Aviation, 1(2), 122-131.

Solvoll, G., \& Hanssen, T. E. S. (2018). Importance of aviation in higher education. Journal of Air Transport Management, 72, 47-55.

Şeker, G. ve Kaya, A. (2018). Lise öğrencilerinin meslek seçiminde aile desteği: Bir ölçek geliştirme çalışması. Türk Psikolojik Danışma ve Rehberlik Dergisi, 8(49), 157-171.

Şimşek, A., Solmaz, R., ve Güleç, E. Yök Atlas Verilerine Göre Gastronomi Ve Mutfak Sanatları Bölümlerinin Değerlendirilmesi: Ege Bölgesi Örneği. Uluslararası Global Turizm Araştırmaları Dergisi, 4(2), 127-137.

Uncular, M. H. (2014). Havacılık Alanında İnsan Kaynağı Yetiştirme ve THY Akademinin Uluslararası Ë̈itim Akreditasyonlart. T.C. Maltepe Üniversitesi Sosyal Bilimler Enstitüsü, İşletme Anabilim Dalı, Yüksek Lisans Tezi

Üzülmez, M., ve Arslan, F. (2019). YÖKATLAS veri tabanına göre Bandırma Onyedi Eylül Üniversitesi'nin etki alanı. In 2nd International Symposium of Bandırma and Surrounding (pp. 17-19).

Vurucu, F. (2010). Meslek lisesi öğrencilerinin meslek seçimi yeterliliği ve meslek seçimini etkileyen faktörler. Yayınlanmamış Yüksek Lisans Tezi, Yeditepe Üniversitesi Sosyal Bilimler Enstitüsü, İstanbul.

Yavaş, V. (2021). Havacılık Yönetimi Öğrencilerine Yönelik İş İlanlarının Analizi. Manisa Celal Bayar Üniversitesi Sosyal Bilimler Dergisi, 19, 121-136.

Yılmaz, M. K. (2017). Yolcu Hizmetlerinde Çalışan Memnuniyeti: Havacılık İşletmelerinde Vardiyalı Çalışanlar Üzerine Bir Araştırma. İnsan ve Toplum Bilimleri Araştırmaları Dergisi, 6(6), 127-137.

YÖK Atlas (2020). Yükseköğretim Program Atlası. Erişim Tarihi: 04.05.2021, https://yokatlas.yok.gov.tr/

Yörükoğlu, F. (2020). Üniversite Öğrencilerinin Bölüm ve Program Seçimlerini Etkileyen Faktörler ve Sosyal Medya Kullanım Davranışı İlişkisi: Karabük Üniversitesi Örneği (Doktora tezi).

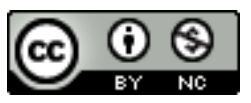

Bu eser Creative Commons Atıf-GayriTicari 4.0 Uluslararası Lisansı 